\title{
Article
}

\section{The Importance of Platelet Glycoside Residues in the Haemostasis of Patients with Immune Thrombocytopaenia}

\author{
Andrés Ramírez-López ${ }^{1,+}{ }^{\circledR}$, María Teresa Álvarez Román ${ }^{1,+}$, Elena Monzón Manzano ${ }^{1}{ }^{\circledR}$, Paula Acuna ${ }^{1}$, \\ Elena G. Arias-Salgado ${ }^{1}$, Mónica Martín Salces ${ }^{1}$, María Isabel Rivas Pollmar ${ }^{1}$, Víctor Jiménez Yuste ${ }^{1,2} \mathbb{D}$, \\ Raul Justo Sanz ${ }^{1}$, Sara García Barcenilla ${ }^{1}$, Tamara Cebanu ${ }^{1}$, Elena González Zorrilla ${ }^{1} \mathbb{C}$ and Nora V. Butta ${ }^{1, *}$ \\ 1 Hematology Unit, La Paz University Hospital-IdiPAZ, Paseo de la Castellana 261, 28046 Madrid, Spain; \\ andres.ramirez1793@gmail.com (A.R.-L.); talvarezroman@gmail.com (M.T.Á.R.); \\ elenamonzonmanzano@hotmail.com (E.M.M.); paulaacbu@gmail.com (P.A.); \\ elenagas@hotmail.com (E.G.A.-S.); monicamsalces@gmail.com (M.M.S.); mirivas718@gmail.com (M.I.R.P.); \\ vjyuste@gmail.com (V.J.Y.); rauljustosanz@gmail.com (R.J.S.); ehemostasia@gmail.com (S.G.B.); \\ tamara.ce@hotmail.es (T.C.); elenaehemostasia@gmail.com (E.G.Z.) \\ 2 Medicine Faculty, Autonomous University of Madrid, Arzobispo Morcillo 4, 28029 Madrid, Spain \\ * Correspondence: nora.butta@salud.madrid.org \\ † A.R.-L. and M.T.Á.R. contributed equally to this work.
}

check for updates

Citation: Ramírez-López, A.; Álvarez Román, M.T.; Monzón Manzano, E.; Acuña, P.; Arias-Salgado, E.G.; Martín Salces, M.; Rivas Pollmar, M.I.; Jiménez Yuste, V.; Justo Sanz, R.; García Barcenilla, S.; et al. The Importance of Platelet Glycoside Residues in the Haemostasis of Patients with Immune Thrombocytopaenia. J. Clin. Med. 2021, 10, 1661. https://doi.org/ $10.3390 /$ jcm 10081661

Academic Editor: Tamam Bakchoul

Received: 8 February 2021

Accepted: 9 April 2021

Published: 13 April 2021

Publisher's Note: MDPI stays neutral with regard to jurisdictional claims in published maps and institutional affiliations.

Copyright: (c) 2021 by the authors. Licensee MDPI, Basel, Switzerland. This article is an open access article distributed under the terms and conditions of the Creative Commons Attribution (CC BY) license (https:// creativecommons.org/licenses/by/ $4.0 /)$.

\begin{abstract}
Loss of sialic acid from the carbohydrate side chains of platelet glycoproteins can affect platelet clearance, a proposed mechanism involved in the etiopathogenesis of immune thrombocytopaenia (ITP). We aimed to assess whether changes in platelet glycosylation in patients with ITP affected platelet counts, function, and apoptosis. This observational, prospective, and transversal study included 82 patients with chronic primary ITP and 115 healthy controls. We measured platelet activation markers and assayed platelet glycosylation and caspase activity, analysing samples using flow cytometry. Platelets from patients with ITP with a platelet count $<30 \times 10^{3} / \mu \mathrm{L}$ presented less sialic acid. Levels of $\alpha 1,6$-fucose (a glycan residue that can directly regulate antibody-dependent cellular cytotoxicity) and $\alpha$-mannose (which can be recognised by mannose-binding-lectin and activate the complement pathway) were increased in the platelets from these patients. Platelet surface exposure of other glycoside residues due to sialic acid loss inversely correlated with platelet count and the ability to be activated. Moreover, loss of sialic acid induced the ingestion of platelets by human hepatome HepG2 cells. Changes in glycoside composition of glycoproteins on the platelets' surface impaired their functional capacity and increased their apoptosis. These changes in platelet glycoside residues appeared to be related to ITP severity.
\end{abstract}

Keywords: immune thrombocytopaenia; platelet apoptosis; sialic acid; platelet activation markers; glycoside residues

\section{Introduction}

Immune thrombocytopaenia (ITP) is an autoimmune disease characterised by a low platelet count $\left(\leq 100 \times 10^{9} / \mathrm{L}\right)$ due to platelet destruction and insufficient platelet production [1]. ITP is considered a rare disease (ORPHA 3002, OMIM 188030) that is diagnosed by ruling out other causes of thrombocytopaenia.

The initial event leading to antiplatelet autoimmunity remains unclear [2]; however, there is strong evidence that autoantibodies and autoreactive CD8+ cytotoxic T cells trigger enhanced platelet destruction and impair platelet production by megakaryocytes in the bone marrow [3]. ITP has been described as a deterioration of the regulatory compartment (regulatory T [Treg] and regulatory B [Breg] cells) of these patients' immune system [4], along with a polarisation of the response towards T helper 1 (Th1) and Th17 cells. The abnormal T-cell function leads to the proliferation and differentiation of self-reactive $B$ cells [5]. 
Many human autoimmune diseases are caused by acquired changes in glycanstructure or in their recognition by specific receptors. Platelets express highly glycosylated proteins on their surface that are involved in platelet haemostatic function and in the platelets' interaction with other cells [6].

The role of glycans in platelet glycoproteins is poorly understood. Typically, glycans affect protein function by (1) guaranteeing proper protein folding, stability and solubility and (2) constituting key binding sites that are recognised by glycan-binding proteins, known as lectins. Glycoside residues are main players in cellular adhesion and intercellular communication [7]. The effects of N-linked and O-linked glycans on the stability of major platelets surface glycoproteins, including GPIb-IX-V, integrin $\alpha \mathrm{IIb} \beta 3$ (GPIIbIIIa) and GPVI, have been studied [8,9]. For example, disruption of the O-linked glycosylation mechanism in mice led to partial proteolysis of the glycoproteins and decreased GPIb-IX-V and $\alpha \mathrm{IIb} \beta 3$ functions, causing defective platelet activation and abnormal morphology, as well as excessive bleeding. The effect of desialylation on the surface glycoproteins of aged and refrigerated platelets has been more widely studied [10,11]. Loss of sialic acid induces the exposure of penultimate galactose that is recognised by hepatic Ashwell-Morell receptors, which leads to platelet clearance and triggers a feedback mechanism to increase platelet production through the hepatic expression of thrombopoietin [12].

Similarly, it has been reported that platelets from some patients with ITP have less sialic acid and that the patients' thrombocytopaenia might improve through treatment with a neuraminidase inhibitor such as oseltamivir in combination with therapies to increase platelet production [13-15].

Nevertheless, there have been no in-depth analyses of glycans on the platelets of patients with ITP. The aim of our study was therefore to perform a comprehensive analysis of the platelet glycan repertoire to better understand their role in platelet function and in the development of ITP.

\section{Materials and Methods}

\subsection{Study Design and Participants}

This was an observational, prospective and transversal study that included patients with chronic primary ITP [1], who were stratified according to their platelet count $\left(>30 \times 10^{3} / \mu \mathrm{L}\right.$ [65 patients] and $<30 \times 10^{3} / \mu \mathrm{L}$ [17 patients]). The study also included a healthy control group (115 participants) recruited from the blood donor section of the Haematology Unit of La Paz University Hospital. Inclusion period was from 10 January 2020 to 20 December 2020.

The study excluded patients with uncontrolled hypertension, hyperlipidaemia, peripheral or coronary artery diseases, abnormal hepatic or renal function, those undergoing therapy with platelet-active drugs and those who had undergone a transfusion within 15 days of the study. Regarding therapy not related to ITP, 3 patients were on antiretroviral therapy, 6 on atorvastatin, 1 on levothyroxine plus simvastatin, 3 on amitriptyline, 2 on lorazepam, 1 on furosemide plus amiodarone, 1 on hidroxicloroquine, 2 on metformin, 5 were receiving iron supplement, and most of the patients were on omeprazol.

The La Paz University Hospital Ethics Committee approved the experimental protocol (PI-3932), and the research study was conducted in compliance with the Helsinki Declaration and after receiving signed informed consent from the participants.

\subsection{Collection and Preparation of Samples}

We collected human peripheral blood samples in 3.8\% sodium citrate and performed blood cell counts with a Coulter Ac.T Diff cell counter (Beckman Coulter, Madrid, Spain). We obtained platelet-rich plasma (PRP) by centrifuging the whole blood (150 $\mathrm{g}$ for $20 \mathrm{~min}$ at $23^{\circ} \mathrm{C}$ ). To obtain washed platelets, we collected the top two-thirds volume of the PRP and centrifuged it $\left(650 \times \mathrm{g}\right.$ for $10 \mathrm{~min}$ at $\left.23^{\circ} \mathrm{C}\right)$ after adding acid-citrate-dextrose (1:10). The pellet was resuspended in an equal volume of HEPES buffer (10 mM HEPES, $145 \mathrm{mM}$ sodium chloride, $5 \mathrm{mM}$ potassium chloride and $1 \mathrm{mM}$ magnesium sulfate, $\mathrm{pH}$ 7.4). 
For the serum preparation, we collected peripheral blood in serum tubes (BD Vacutainer, Plymouth, UK) and separated it by centrifuging clotted blood $(2500 \times \mathrm{g}$ for $15 \mathrm{~min}$ at $23^{\circ} \mathrm{C}$ ). The plasma and serum aliquots were stored at $-80^{\circ} \mathrm{C}$ until analysis.

\subsection{Determination of Platelet Activation Markers}

We diluted the PRP 1:5 with HEPES buffer and incubated it with $100 \mu \mathrm{M}$ of thrombin receptor-activating peptide 6 (TRAP, Bachem, Switzerland) or $20 \mu \mathrm{M}$ of adenosine diphosphate (ADP, SIGMA, Madrid, Spain) at room temperature. Following incubation, we added fluorescein-isothiocyanate (FITC)-PAC1 (BD, Madrid, Spain), a monoclonal antibody (mAb) that recognises activated conformation of fibrinogen receptor, or FITC-labelled anti-human P-selectin mAb (BD Pharmingen, San Diego, CA, USA) or FITC-anti-CD63 mAb (Becton Dickinson, Madrid, Spain) for $15 \mathrm{~min}$ at room temperature in the dark.

We determined the surface expression of the fibrinogen receptor by labelling diluted PRP with phycoerythrin (PE)-mAbs against its $\alpha \mathrm{IIb}$ (CD41, BioCytex, Marseille, France) and FITC-mAb against its $\beta 3$ (Becton Dickinson) subunits. Surface expression of von Willebrand factor (VWF) receptor was determined using FITC-mAbs against its CD42a and CD42b subunits (BD Pharmingen, Madrid, Spain).

After incubation, all samples were diluted in PBS buffer for flow cytometry analysis with a FACScan flow cytometer (BD Biosciences, Madrid, Spain), and 10,000 events in the platelet region were acquired and analysed with BD CellQuest Pro $^{\mathrm{TM}}$ software (BD Biosciences, Madrid, Spain).

\subsection{Lectin Binding Studies}

We incubated washed platelets $\left(50 \times 10^{3}\right.$ platelets $\left./ \mu \mathrm{L}\right)$ with FITC-labelled lectins $(10$ $\mu \mathrm{g} / \mathrm{mL}$, Vector Laboratories, Barcelona, Spain), as listed in Table 1 , for $30 \mathrm{~min}$ at $37^{\circ} \mathrm{C}$ and analysed them by flow cytometry.

Table 1. Lectins used in flow cytometry experiments and their glycoside binding specificity.

\begin{tabular}{cccccc}
\hline Lectin & $\begin{array}{c}\text { Aleuria } \\
\text { Aurantia }\end{array}$ & Concavalin A & $\begin{array}{c}\text { Datura } \\
\text { Stramonium }\end{array}$ & $\begin{array}{c}\text { Ricinus Communis } \\
\text { Agglutinin I }\end{array}$ & $\begin{array}{c}\text { Wheat Germ } \\
\text { Agglutinin }\end{array}$ \\
\hline Abbreviation & AA & C & DS & RCA & WGA \\
\hline Sugar specificity & $\alpha 1,6$-Fucose & $\alpha$-Mannose & GalNAc & $\begin{array}{c}\text { Galactose } \\
\text { GalNAc }\end{array}$ & $\beta-G l c N A c$ \\
\hline
\end{tabular}

GalNAc: N-acetylgalactosamine; $\beta$-GlcNAc: N-acetylglucosamine.

\subsection{Measurement of Apoptosis Markers in Platelets}

We assessed the surface exposure of phosphatidylserine in washed platelets by measuring the binding of FITC-labelled annexin V (BD Pharmingen, Madrid, Spain). Briefly, washed platelets were resuspended in annexin V binding buffer (10 mM HEPES, $10 \mathrm{mM}$ sodium hydroxide, $140 \mathrm{mM}$ sodium chloride, $2.5 \mathrm{mM}$ calcium chloride, $\mathrm{pH}$ 7.4) and labelled with FITC-annexin V. After a 15-min incubation period with either buffer or $1 \mu \mathrm{M}$ ionomycin (Sigma, Madrid, Spain) at room temperature in the dark, the samples were analysed by flow cytometry.

To analyse active caspase- $3,-8$ or -9 , we diluted PRP 10-fold with isotonic HEPES buffered saline with calcium ion ( $150 \mathrm{mM}$ sodium chloride, $2 \mathrm{mM}$ calcium chloride, $2 \mathrm{mM}$ magnesium chloride, 2 mM HEPES, pH 7.4), 2 mM Gly-Pro-Arg-Pro (SIGMA, Madrid, Spain) and either FAM-DEVD-FMK, FAM-LETD-FMK or FAM-LEHD-FMK (Millipore, Madrid, Spain).

\subsection{Neuraminidase Activity}

We measured neuraminidase (NEU) activity in plasma and serum from the healthy controls and patients with ITP according to van der Wal et al. [16]. Briefly, we treated either plasma or serum with $75 \mu \mathrm{M}$ of sodium acetate (pH 4.5), $0.1 \%$ Triton X-100 and $0.5 \mathrm{mM}$ 
2'-(4-methylumbelliferyl)- $\alpha$-D-N-acetylneuraminic acid sodium salt hydrate (MUNANA, Merck, Madrid, Spain) in 96-well plates. We measured the fluorescence at beginning (time 0 ) and at 10, 15, 30, and $60 \mathrm{~min}$ after initiating the reaction (excitation $\lambda \mathrm{ex}=365 \mathrm{~nm}$, emission $\lambda \mathrm{em}=450 \mathrm{~nm}$ ).

\subsection{HepG2 Uptake of Platelets}

Human HepG2 cells were grown in DMEM (Invitrogen, Madrid, Spain) supplemented with $10 \%$ heat-inactivated foetal calf serum (Lonza, Madrid, Spain) and penicillin/streptomycin at $37^{\circ} \mathrm{C}$ and $5 \%$ carbon dioxide.

We seeded the HepG2 cells $\left(1 \times 10^{5}\right.$ /well $)$ onto 24 -well plates, allowed them to adhere for $24 \mathrm{~h}$ and then starved them for $30 \mathrm{~min}$ with serum-free media. The assay was initiated by adding platelets from healthy controls or patients with ITP $\left(5 \times 10^{7} /\right.$ well $)$ previously labelled with $100 \mu \mathrm{M}$ of CMFDA Cell Tracker (ThermoFisher Scientific, Madrid, Spain). HepG2 cells and platelets were incubated together for $45 \mathrm{~min}$ at $37^{\circ} \mathrm{C}$ with gentle shaking. We washed the cultures three times and separated the HepG2 cells from the plates and from the surface-adhered platelets with a solution of trypsin/EDTA. After washing the HepG2 cells, we analysed them by flow cytometry according to their forward and side scatter features, and those that contained ingested platelets were identified by their fluorescence.

\subsection{Statistical Analysis}

We employed the Shapiro-Wilk test to assess the data distribution, and the results are presented as mean \pm SD or median (p25-p75) depending on their distribution. We assessed differences between 2 groups using the 2-tailed unpaired Student's $t$-test or the nonparametric Mann-Whitney U-test, as appropriate. To compare multiple groups, we performed a one-way analysis of variance or Kruskal-Wallis with Dunn's multicomparison tests. The correlation analysis was performed using Pearson's or Spearman's test. We employed GraphPad Prism 5 software (GraphPad Software version 5.03) for all statistical analyses and set the significance at $p \leq 0.05$.

\section{Results}

3.1. Features of Patients with Immune Thrombocytopaenia

Table 2 lists the characteristics of the patients with ITP.

Table 2. Therapeutic treatments of patients with immune thrombocytopaenia (ITP).

\begin{tabular}{|c|c|c|c|c|c|c|}
\hline & \multicolumn{3}{|c|}{$<30,000$ Platelets $/ \mu \mathrm{L}$} & \multicolumn{3}{|c|}{$>30,000$ Platelets $/ \mu \mathrm{L}$} \\
\hline & Gender (\%) & $\begin{array}{c}\text { Age } \\
\text { Mean } \pm \text { SD }\end{array}$ & $\begin{array}{l}\text { Concomitant } \\
\text { Medication } \\
\text { (No Patients) }\end{array}$ & Gender (\%) & $\begin{array}{c}\text { Age } \\
\text { Mean } \pm S D\end{array}$ & $\begin{array}{l}\text { Concomitant } \\
\text { Medication } \\
\text { (No Patients) }\end{array}$ \\
\hline No treatment & $\begin{array}{l}\text { M: } 2(50) \\
\text { F: } 2(50)\end{array}$ & $49 \pm 21.6$ & - & $\begin{array}{l}\text { M: } 11(34) \\
\text { F: } 21(66)\end{array}$ & $56 \pm 19$ & +Anticoagulant: 3 \\
\hline Eltrombopag & $\begin{array}{l}\text { M: } 3(50) \\
\text { F: } 3(50)\end{array}$ & $46 \pm 11.8$ & $\begin{array}{c}\text { +IGIV }(2) \\
\text { +Corticosteroids } \\
(1) \\
\text { +Corticosteroids + } \\
\text { azathioprine }(2)\end{array}$ & $\begin{array}{l}\text { M: } 3(21) \\
\text { F: } 11(79)\end{array}$ & $54 \pm 21.5$ & $\begin{array}{c}\text { +IGIV: } 1 \\
\text { +Anticoagulant: } 5\end{array}$ \\
\hline Romiplostim & $\begin{array}{l}\text { M: 3(50) } \\
F: 3(50)\end{array}$ & $58 \pm 25.9$ & - & $\begin{array}{l}\text { M: } 9(56) \\
\text { F: } 7(44)\end{array}$ & $57 \pm 19.5$ & $\begin{array}{c}\text { +IGIV: } 1 \\
\text { +Corticosteroids: } 5\end{array}$ \\
\hline IGIV & $\begin{array}{l}\text { M: } 0(0) \\
\text { F: } 1(100)\end{array}$ & 62 & - & - & - & - \\
\hline Corticosteroids & - & - & - & $\begin{array}{c}\text { M: } 0 \\
\text { F: } 3(100)\end{array}$ & $51 \pm 2.5$ & $\begin{array}{c}\text { +IGIV: } 2 \\
\text { +Rituximab: } 1\end{array}$ \\
\hline
\end{tabular}


Figure 1 indicates the platelet counts for the healthy controls and ITP groups, showing that the platelets from the patients with ITP had a higher mean platelet volume (MPV) than those from the controls (Figure 1). Moreover, the lowest platelet count was accompanied by the highest MPV (Spearman $\rho=-0.562, p<0.0001$ ).
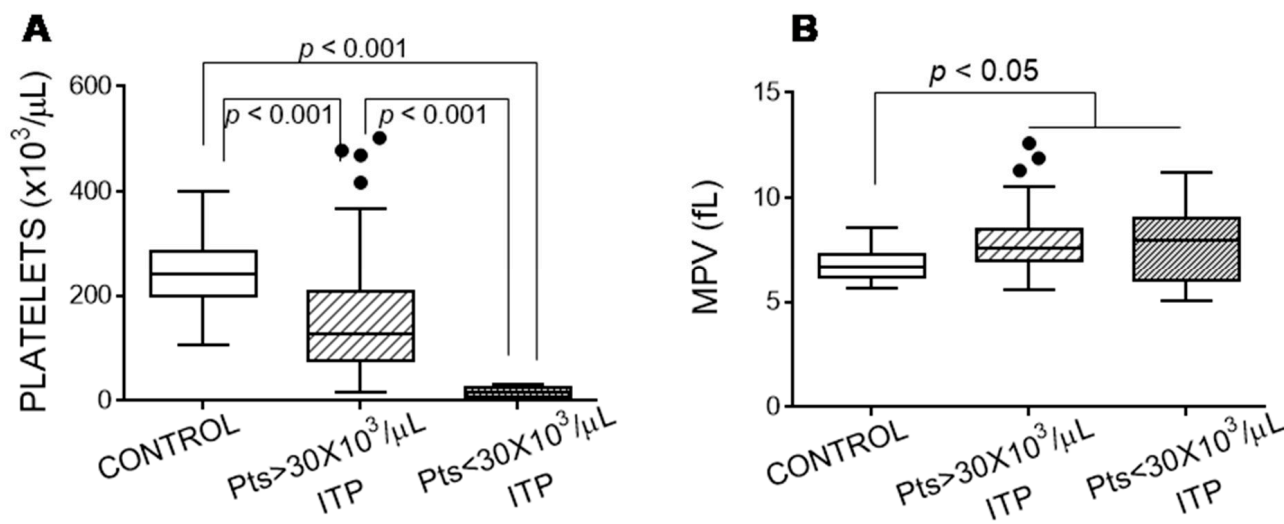

Figure 1. Platelet features in the patients with immune thrombocytopaenia (ITP). (A) Platelet count and (B) mean platelet volume (MPV). We performed Kruskal-Wallis and Dunn's multiple comparison tests and considered a $p$-value of $<0.05$ as significant.

\subsection{Exposure of Glycoside Residues on the Platelet Surface}

Given that the platelets from the patients with ITP had a larger volume than those of the controls, we expressed the glycoside composition of the platelet surface as the ratio between the mean fluorescence of the binding of lectins and MPV. Figure 2 shows that the platelets from the patients with ITP had a different glycosylation pattern on their surface than the healthy controls, and this difference was more pronounced in the platelets from the patients with ITP with $<30 \times 10^{3}$ platelets $/ \mu \mathrm{L}$.
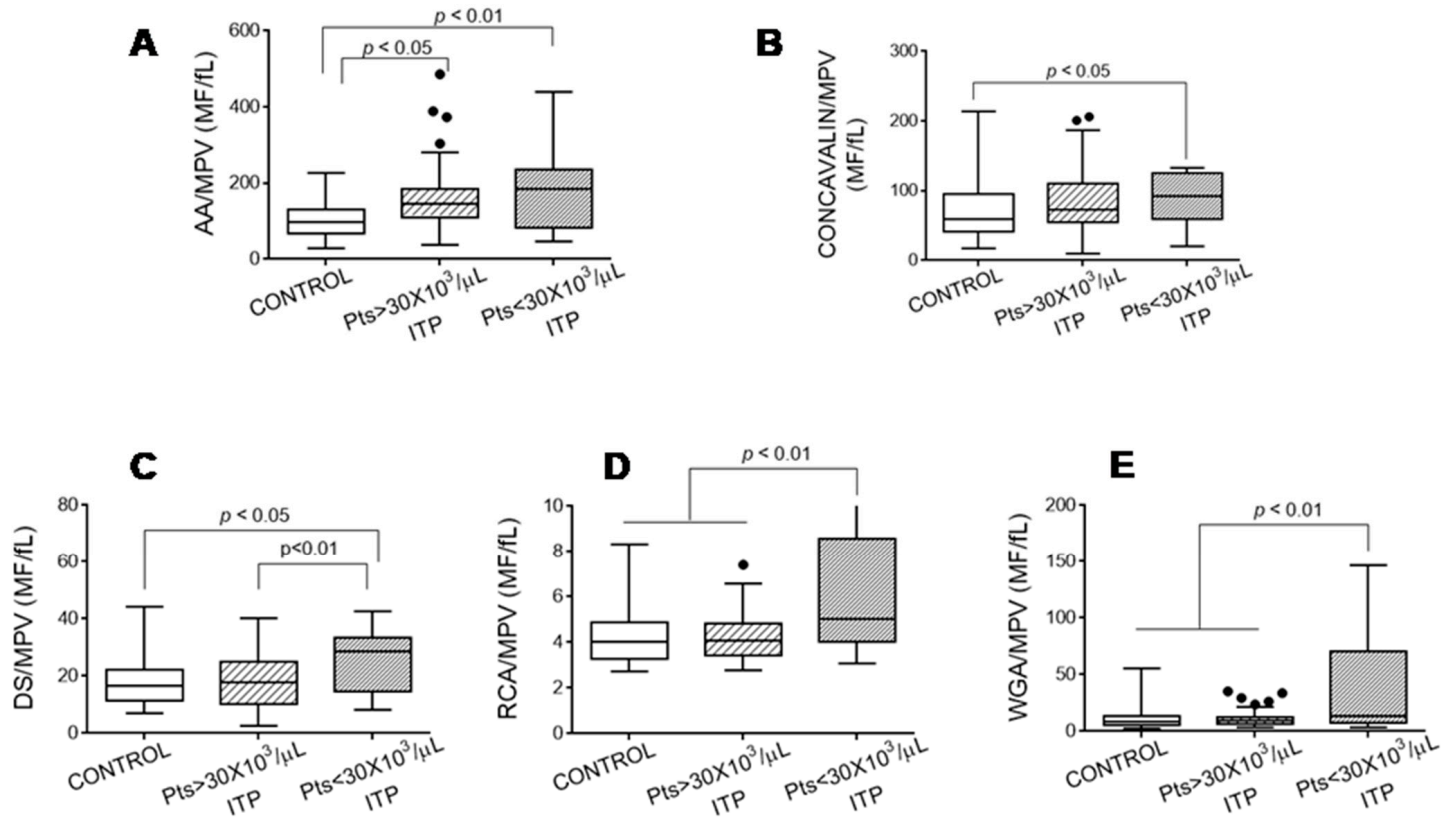

Figure 2. Lectin binding was determined in quiescent platelets from the controls and patients with immune thrombocytopaenia. Data are expressed as the ratio between the mean fluorescence of positive cells (MF) and mean platelet volume (MPV). The following lectins were tested: (A) Aleuria aurantia (AA), (B) Concanavalin A, (C) Datura stramonium (DS), (D) Ricinus communis agglutinin (RCA), and (E) Wheat germ agglutinin (WGA). We performed Kruskal-Wallis and Dunn's multiple comparison tests and considered a $p$-value of $<0.05$ as significant. 


\subsection{Platelet Activation Markers}

We determined the platelets' ability to be activated after agonist stimulation in our cohorts. Platelets from the patients with ITP with $<30 \times 10^{3}$ platelets $/ \mu \mathrm{L}$ had a lower capacity to be activated, as shown through the reduced binding of PAC1 to fibrinogen receptors (Figure 3A) and the diminished exposure of P-selectin and CD63, released, respectively, from alpha and dense granules (Figure 3B,C). This impairment in the platelets' stimulation capacity was not due to a reduced content of fibrinogen receptor (Figure 3D). Moreover, platelets from ITP patients also exposed similar levels of VWF receptor on their surface (Figure 3D).
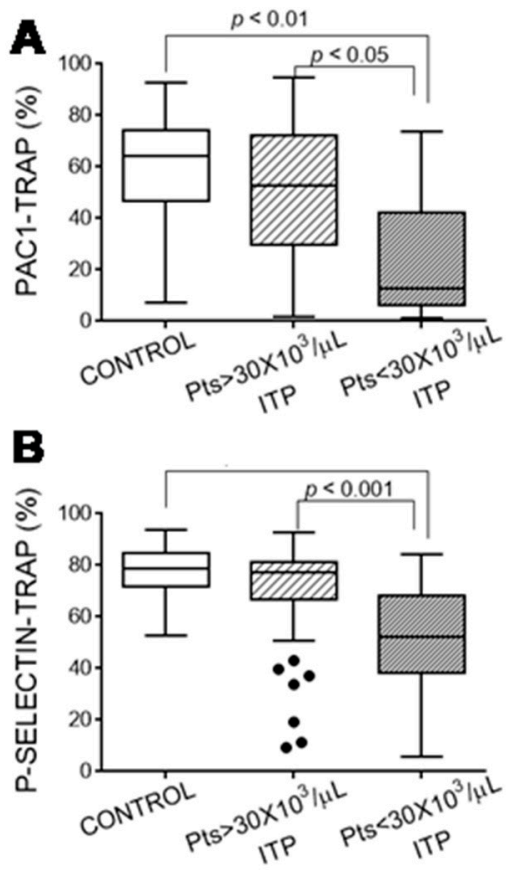
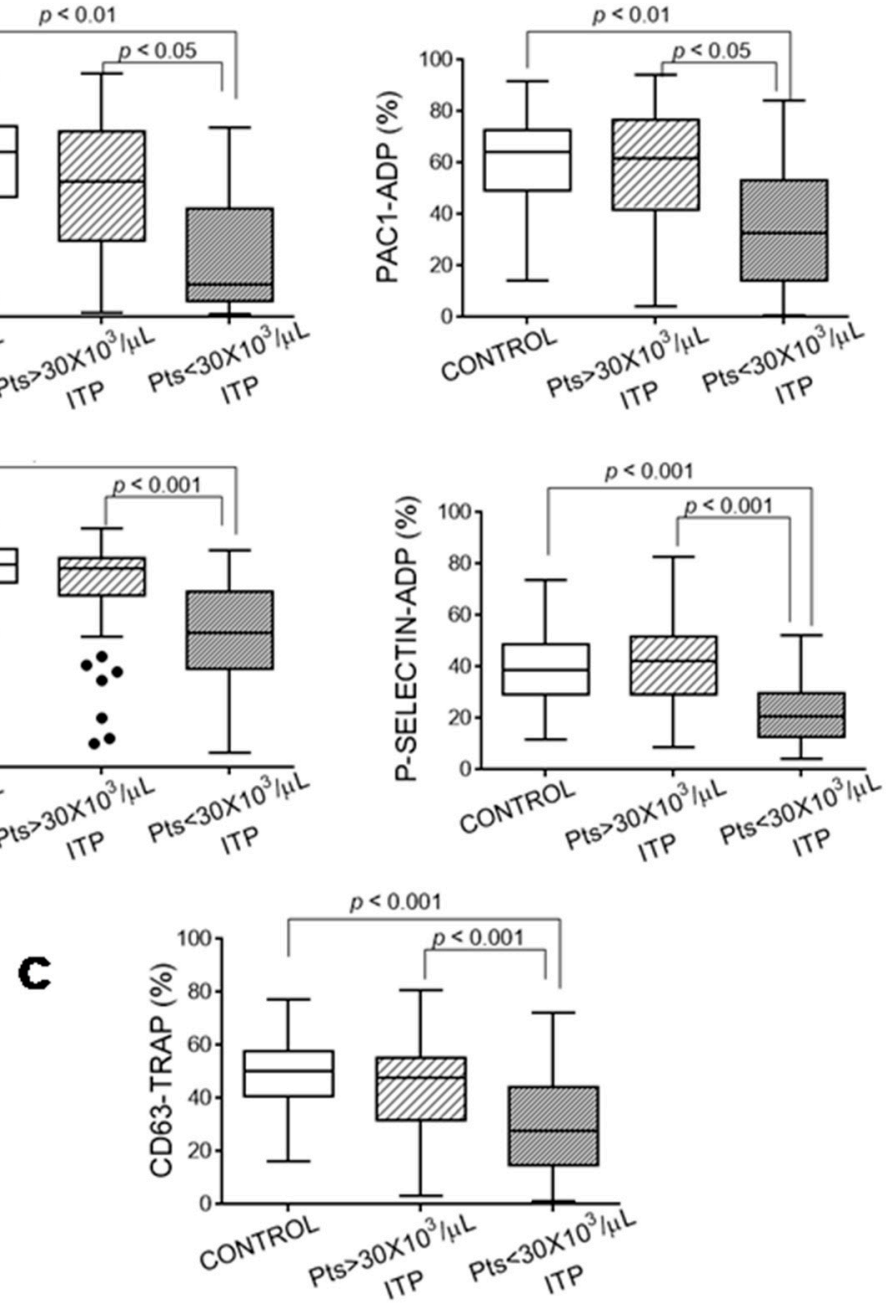

D
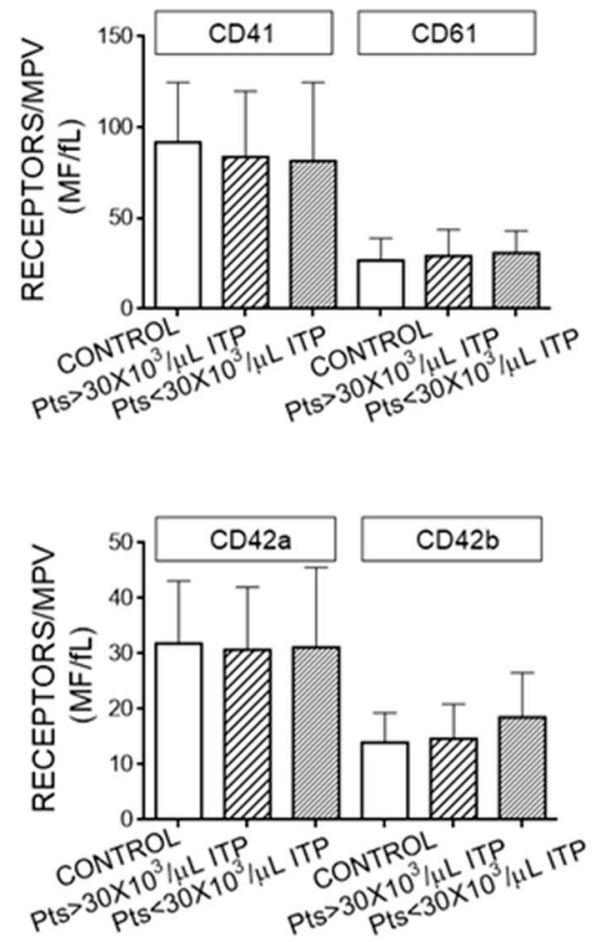

Figure 3. Platelet activation markers. Platelets from healthy controls and from patients with immune thrombocytopaenia (ITP) stimulated with thrombin receptor-activating peptide (TRAP) and ADP were incubated with fluorescein isothiocyanate (FITC)-PAC1 (A), FITC-anti-P-selectin monoclonal antibody (mAb) (B) or FITC-anti-CD63 mAb (C). The data in (A-C) are expressed as percentage of positive cells. (D) Fibrinogen receptor (subunits CD41 and CD61) and VWF receptor (subunits $\mathrm{CD} 42 \mathrm{a}$ and $\mathrm{CD} 42 \mathrm{~b}$ ) are expressed as the ratio between mean fluorescence (MF) and mean platelet volume (MPV). All samples were analysed by flow cytometry. We performed Kruskal-Wallis and Dunn's multiple comparison tests and considered a $p$-value $<0.05$ as significant.

The patients with the lowest platelet count showed the most pronounced decrease in platelet activation markers induced by TRAP stimulation (platelet count vs. PAC1 binding: $\rho=0.392, p<0.001$; vs. P-selectin $\rho=0.451, p<0.001$; and vs. CD63 exposure $\rho=0.229$, $p<0.001)$. 


\subsection{Apoptosis Markers of Platelets}

Platelets from the patients with ITP and a platelet count $<30 \times 10^{3} / \mu \mathrm{L}$ showed more pronounced signs of apoptosis (Figure 4). In another cohort of patients with ITP, we previously reported an inverse relationship between platelet apoptosis and the platelets ability to be activated by agonists [4]. We confirmed that this association was also true in individuals included in the present study (TRAP-induced PAC binding vs. caspase 3: $\rho=-0.262, p<0.001$; vs. caspase $8: \rho=-0.301, p<0.001$; and vs. caspase 9: $\rho=-0.228$, $p<0.01)$.
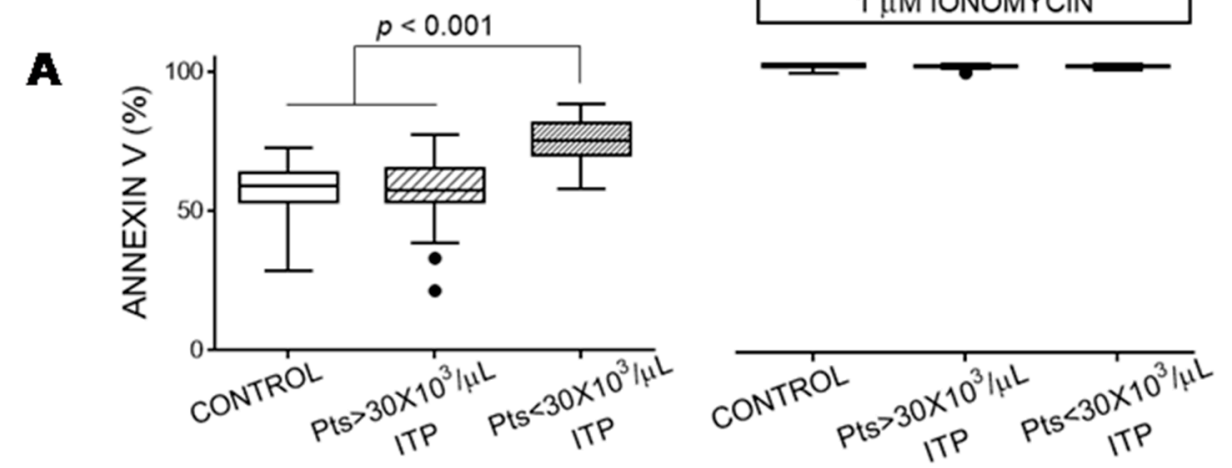

\section{B}
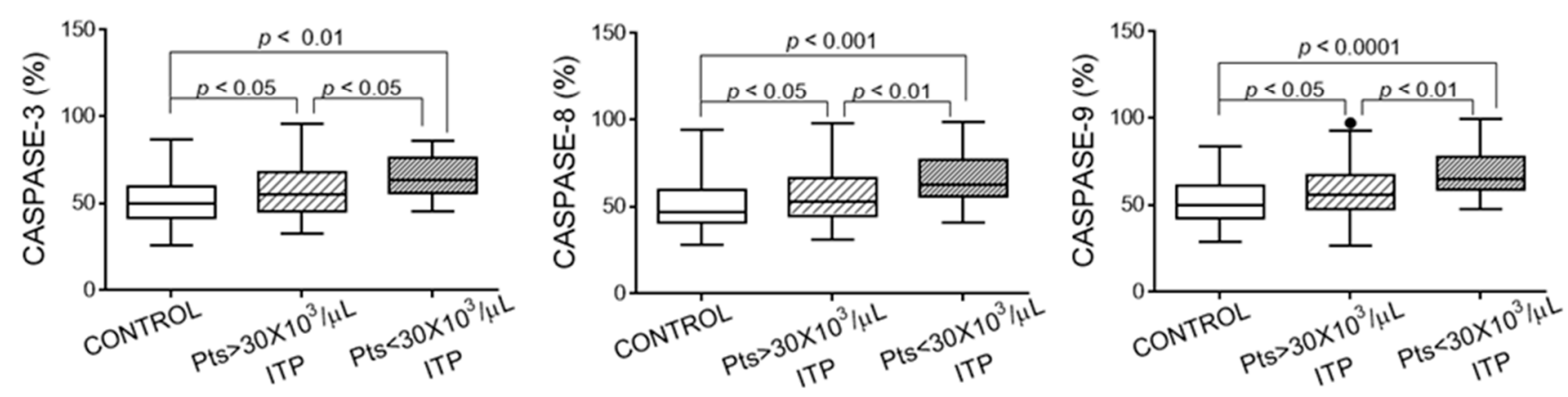

Figure 4. Apoptosis signs of platelets. (A) Phosphatidylserine surface exposure determined by binding of fluorescein isothiocyanate (FITC)-annexin V in platelets incubated with either buffer or ionomycin, and (B) caspase activities in quiescent platelets from controls and patients with immune thrombocytopaenia (ITP) were determined by flow cytometry analysis. Data are expressed as percentage of positive cells. We performed Kruskal-Wallis and Dunn's multiple comparison tests and considered a $p$-value $<0.05$ as significant.

\subsection{Relationship between Glycosylation and Platelet Functional Characteristics}

We studied whether there was a relationship between glycosylation on the platelet surface and platelet functional features. We observed that the platelet count and the ability to be stimulated were related to glycoside residues on the platelet surface (Table 3). Particularly, the loss of sialic acid residues (measured indirectly through the RCA binding) appeared to be a key player in reducing platelet counts (Figure 5A) and the platelets' ability to be activated (Figure 5B). Moreover, lower sialic acid exposure on the platelet surface corresponded to higher activity of platelet caspases (Figure 5C). 
Table 3. Correlation between glycoside exposure and platelet count and ability of fibrinogen receptor to be activated.

\begin{tabular}{ccccc}
\hline $\begin{array}{c}\text { Recognised Glycoside Residue } \\
\text { (Lectin) }\end{array}$ & $\begin{array}{c}\alpha-1,6 \text { Fucose } \\
\text { (AA) }\end{array}$ & $\begin{array}{c}\alpha \text {-Mannose } \\
\text { (C) }\end{array}$ & $\begin{array}{c}\text { GalNAc } \\
\text { (DS) }\end{array}$ & $\begin{array}{c}\beta-G l u N A c \\
\text { (WGA) }\end{array}$ \\
\hline $\begin{array}{c}\text { Lectin binding vs. Platelet count } \\
\text { Spearman } \rho, p)\end{array}$ & $-0.3946 ; 0.0002$ & $-0.3964 ; 0.0002$ & $-0.4091 ; 0.0001$ & $-0.2868 ; 0.0177$ \\
$\begin{array}{c}\text { Lectin binding vs. TRAP-PAC1 } \\
\text { binding (Spearman } \rho, p)\end{array}$ & $-0.2297 ; 0.392$ & $-0.2567 ; 0.040$ & $-0.2581 ; 0.0185$ & $-0.3737 ; 0.0007$ \\
\hline
\end{tabular}

AA: Aleuria aurantia; C: Concanavalin A; DS: Datura stramonium, GalNAc: N-acetylgalactosamine; WGA: Wheat germ agglutinin; $\beta$-GlcNAc: N-acetylglucosamine. Correlation was determined by Spearman's test, and a $p$-value $<0.05$ was considered significant.

B
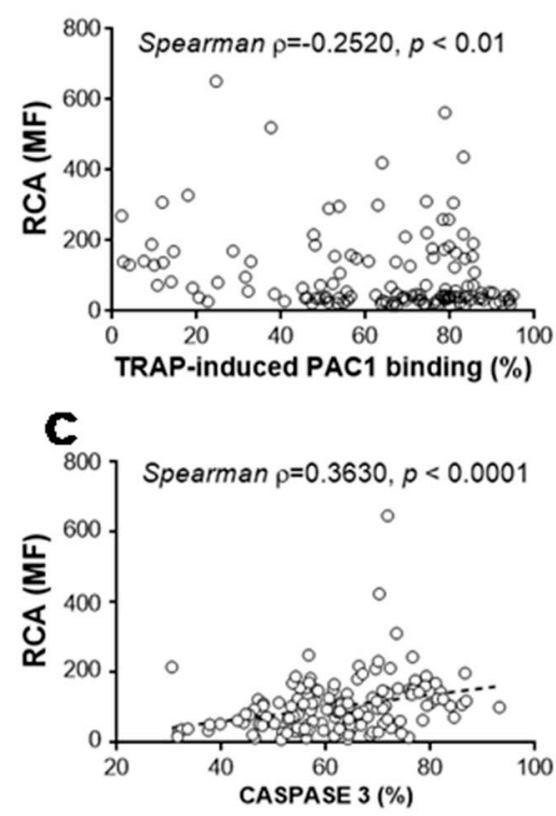

\section{A}
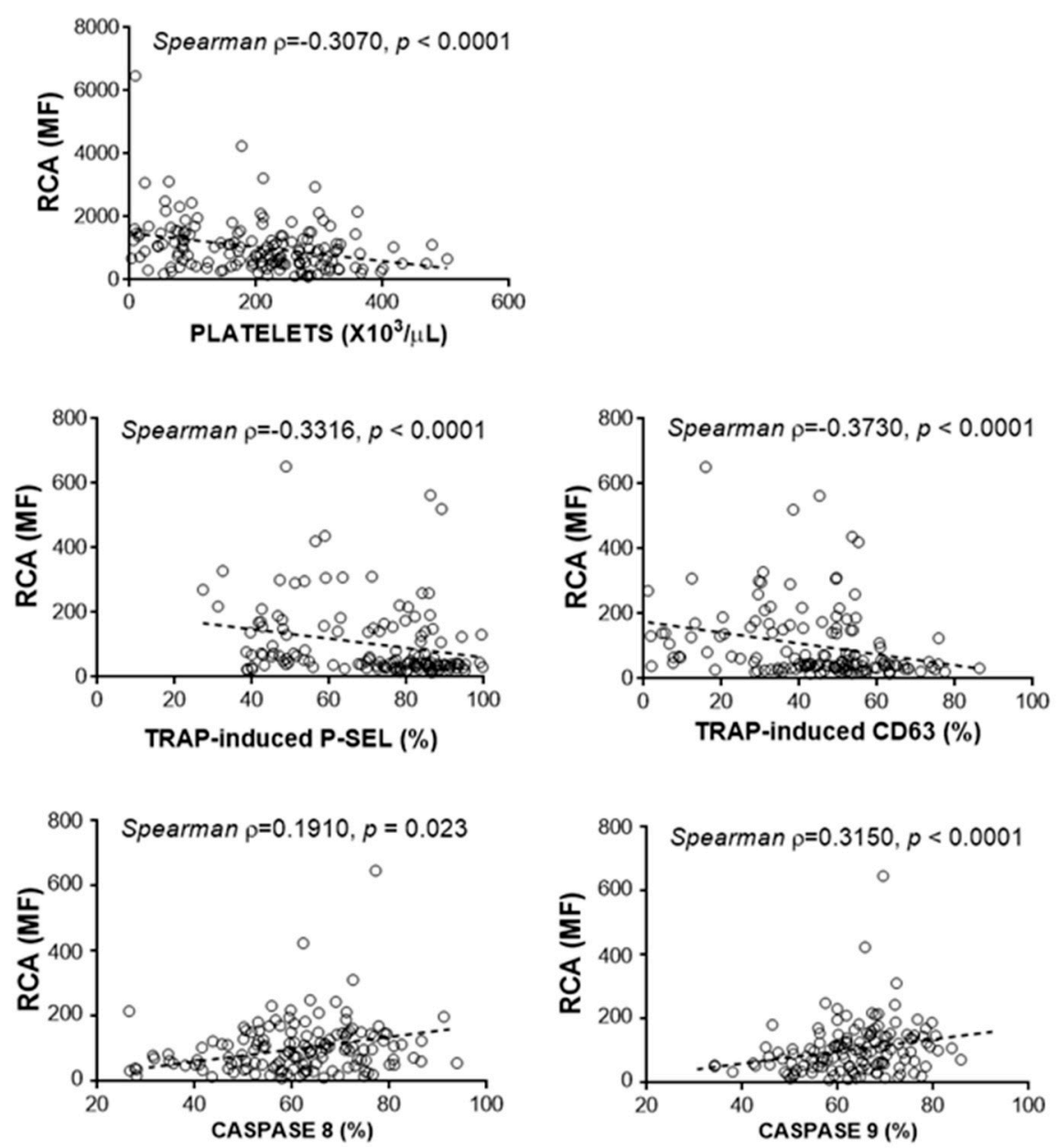

Figure 5. Loss of sialic acid was indirectly determined through the binding of Ricinus communis agglutinin (RCA). Correlation between RCA binding and platelet count (A), platelet activation markers (B), and caspase activities in quiescent platelets $(\mathbf{C})$ was determined by Spearman's test, and a $p$-value $<0.05$ was considered significant.

\subsection{Neuraminidase Activity in Plasma and Serum}

Neuraminidase is an enzyme that mediates the release of sialic acid. We therefore measured its activity and relationship with RCA binding and the platelets' capacity to be activated. Neuraminidase activity measured over time was higher in the serum from the patients with ITP than in the serum from the healthy controls, whereas there was no difference in plasma neuraminidase activity between these groups (Figure 6A). As expected, we found a direct relationship between neuraminidase activity in serum and RCA binding to platelets $(\rho=0.7030, p<0.001)$. 


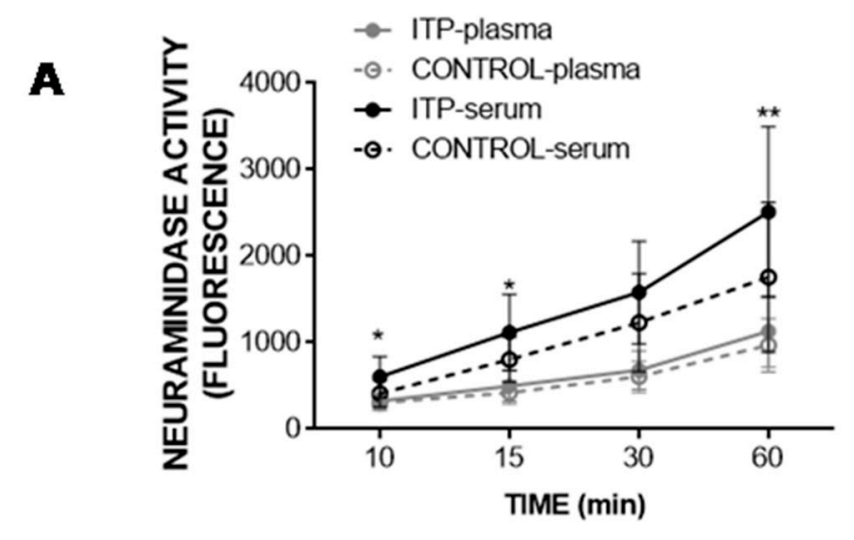

B

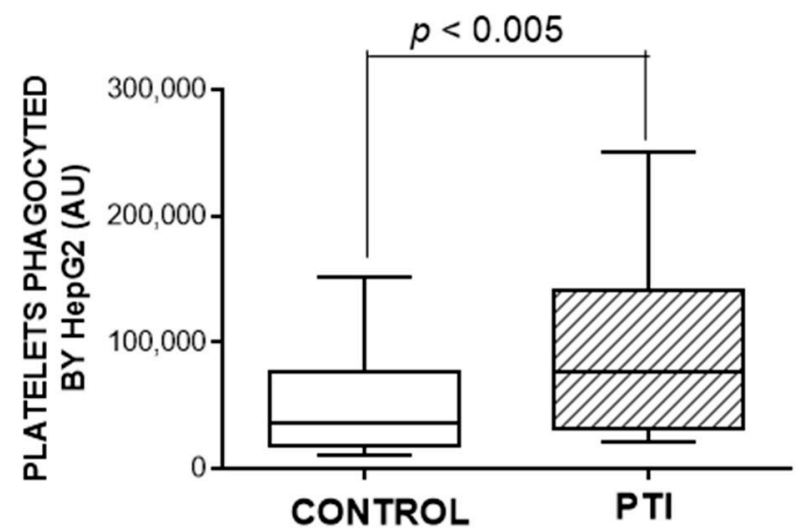

123

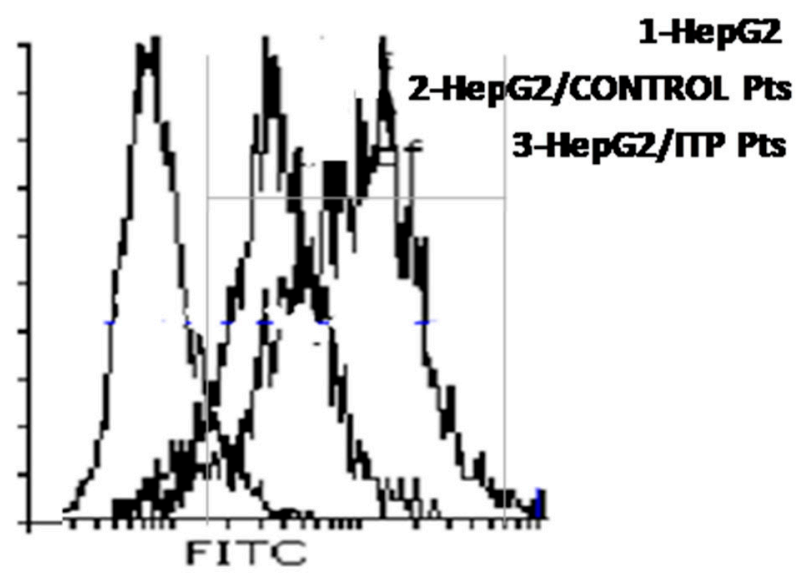

Figure 6. (A) Neuraminidase activity was measured in either serum (black lines) or plasma (grey lines) from healthy controls (open circles) and patients with immune thrombocytopaenia (closed circles), according to the Methods section. (B) HepG2 cell ingestion of human platelets in vitro. Ingestion of CMFDA-labelled platelets was detected by flow cytometry as an increase in hepatocyte-associated fluorescence ( $y$-axis, in arbitrary units, AU). Representative flow cytometry histograms are shown. Mann-Whitney test was performed to determine the differences between the control and immune thrombocytopaenia groups, and a $p$-value $<0.05$ was considered significant.

Supporting the involvement of sialic acid in platelet activation capacity, we observed an inverse correlation between neuraminidase activity in serum and TRAP-induced PAC binding $(\rho=-0.453, p<0.05)$.

\subsection{HepG2-Based Platelet Ingestion Assay}

We determined the degree of labelled platelets ingested by HepG2 cells by flow cytometry. As shown in Figure 6B, HepG2 cells ingested more platelets isolated from the patients with ITP than platelets from the healthy control group. The lower exposure of sialic acid induced the highest ingestion of platelets $(\rho=0.5510, p<0.01)$.

\section{Discussion}

Our results revealed a close relationship between ITP severity (evaluated through platelet counts and the platelets' ability to be activated) and loss of sialic acid from glycoproteins on the platelets' surface. The three major glycosylated proteins in the platelet glycocalyx are P-selectin (13,000 copies per activated platelet), the GPI-IX complex (CD42a/CD42b, 25,000 copies per platelet), and the integrin GPIIbIIIa (CD41/CD61; 50,000 copies per platelet) [17].

Loss of sialic acid is responsible for increasing platelet clearance through the hepatic Ashwell-Morell receptors present in liver cells [18]. Along these lines, we demonstrated 
that platelets with the lowest exposure of sialic acid were the most ingested by human hepatome HepG2 cells. Desialylation of platelet glycoproteins might be due to their sialidase activity, which relies on 4 sialidases (NEU1-NEU4) that are found at different locations and have different affinities for their substrates $[19,20]$. NEU1, NEU2, and NEU4 are present on the surface of quiescent platelets. Exposure of NEU1 and NEU2 on the platelet surface increased after specific clustering of GPIb activated by VWF, which mobilised them from their intracellular stores (mitochondria for NEU1 and $\alpha$-granules for NEU2) [16]. Another situation that upregulates NEU1 on the platelet surface is the presence of anti-GPIb $\alpha$ antibodies, such as those present in some patients with ITP [18,21]. Our data showed that platelets from most of our patients with ITP had less sialic acid than the platelets from the healthy controls, despite the fact that anti-GPIb antibodies were detected only in one of the patients whose platelets did not have any singular feature when compared with those from the patients with ITP with similar platelet counts $\left(134 \times 10^{3} / \mu \mathrm{L}\right)$. Moreover, the agonists employed in our experiments to stimulate platelets did not induce NEU1 and NEU2 expression on the platelet surface [16]. We also observed that serum (but not plasma) from the patients with ITP had an increased neuraminidase activity, suggesting a cellular source for the enzyme. Taken together, our data suggest that other mechanisms underlying the changes in platelet surface glycosylation must be at play. For example, it has been reported that CD8+ T cells from patients with ITP with positive cytotoxicity induced significant platelet desialylation, NEU1 expression on the platelet surface, and platelet phagocytosis by hepatocytes in vitro [22].

Studies have reported that desialylated GPIba has an increased ability to be activated by ristocetin and to bind to VWF [23,24]. Moreover, a study elegantly demonstrated that NEU1 and NEU2 are specifically translocated to the membrane following VWF-mediated GPIba-clustering and that this event produces desialylation that potentiates the ability of $\alpha \operatorname{IIb} \beta 3$ to bind to fibrinogen [25]. This observation does not contradict our results (a diminished activation of fibrinogen receptor due to the loss of sialic acid) because we specifically tested platelet activation through the inside-out stimulation of fibrinogen receptor with no involvement of the VWF receptor. Another example of thrombocytopaenia due to desialylation induced by excessive binding of VWF to platelets is that observed in patients infected by the dengue virus [26]. Further supporting our results, the treatment of platelets with neuraminidase reduced their aggregation induced by ADP [27]. Moreover, abnormalities in the N-glycosylation of GPVI could contribute to acquired defects in GPVI-mediated platelet reactivity to collagen $[8,28,29]$.

The function of platelet receptors that mediate their adhesive and aggregative properties are strongly reliant upon $\mathrm{N}$-glycosylation to modulate the orientation of glycoproteins to facilitate interaction between proteins [29]. A mutational study performed on $\beta 3$ demonstrated that loss of $\mathrm{N}$-glycoside sites impaired either $\alpha \mathrm{IIb} \beta 3$ expression or function. The first possibility does not seem to explain our results because we did not detect a decrease in the surface expression of fibrinogen receptor [30]. Therefore, the platelets' diminished function might be explained by the fact that many of these N-glycan sites lie in the domain interfaces that are rearranged during integrin activation.

Another cause for the reduced exposure of sialic acid on the platelet surface might be a decrease in glycosyltransferase activity. Three distinct glycosyltransferase families were found within and on the surface of platelets [31]. Supporting the importance of sialyl transferases in the platelets' lifespan, mice lacking ST3GAL4 (an enzyme that transfers sialic acid onto $\beta 1$,4-galactose) develop thrombocytopaenia due to increased platelet clearance via the hepatic Ashwell-Morell receptor [32]. Moreover, the lack of ST3GAL1 (an enzyme that caps the Thomsen-Friedenreich antigen with sialic acid) was associated with platelet counts 50\% lower than normal, as observed in ST3GAL1-null mice [33,34].

Platelets from ITP patients showed more signs of apoptosis. The percentage of resting control platelets positive for annexin $\mathrm{V}$ maybe higher than those observed by other authors, but it has been reported that variations in experimental conditions may explain these differences [35]. We found a direct correlation between the loss of sialic acid and the activity 
of platelet caspases 3, 8, and 9 (present results and those of Monzon Manzano et al. [4]). Moreover, it has been reported that ABT-737 (an inhibitor of Bcl-2 family proteins) induced apoptosis of dog platelets, with the primary platelet clearance site being the liver [10]. Nevertheless, Grodzielski et al. proposed that platelet apoptosis and loss of sialic acid were not necessarily related [36].

Desialylation was the main focus of this study. However, we also detected changes in the distribution of other glycoside residues in the platelets from the patients with ITP, as well as an inverse correlation between $\alpha 1,6$-fucose, $\alpha$-mannose, GalNAc, and $\beta$-GlcNAc exposure and platelet count and activation capacity of the fibrinogen receptor. Enhanced exposure of $\beta$-GlcNAc was revealed through the increased binding of WGA to platelets from the patients with ITP and might indicate another mechanism of platelet destruction given that $\beta$-GlcNAc residues can be recognised by the $\alpha_{M} \beta 2$ hepatic macrophage receptors and phagocytosed by these cells [37,38], as was reported for cold-storage platelets [11]. This mechanism for platelet clearance seemed to be independent of that mediated by Ashwell-Morell receptors, because HepG2 cells express both chains (ASGR1 and ASGR2) of the Ashwell-Morell receptor but do not express $\alpha_{\mathrm{M}} \beta 2$. Moreover, Rumjantseva et al. [11] demonstrated that macrophage-mediated clearance was operative for platelets chilled for $4 \mathrm{~h}$, whereas refrigeration for a longer period $(24 \mathrm{~h})$ induced the removal of platelets through hepatic Ashwell-Morell receptors.

Changes in glycoside composition on the surface of platelets from patients with ITP might also have consequences for complement activation. Collectins (e.g.,mannosebinding lectin) and ficolins are pattern-recognising molecules that are not only reactive against pathogen-associated molecular patterns but also to aberrantly glycosylated self cell-surface structures [39]. These lectin pathway-related pattern-recognising molecules of the complement recognise residues of carbohydrates such as D-mannose, GlcNAc, and L-fucose, all of which are increased on the surface of platelets from patients with ITP. Moreover, mannose-binding lectin binds to platelets [40], and sialic acid residues inhibit its binding to cells [41]. It is therefore tempting to speculate that a complement is involved in the etiopathogenesis of ITP, as proposed by numerous authors [42,43].

\section{Conclusions}

Our data suggest the importance of glycoside residues present on the surface of platelets for determining their count and functionality in patients with ITP. Moreover, the results of this study encourage future studies to further elucidate the participation of the platelet glycome in the etiopathogenesis of ITP, given that the presence of sialic acid is a good sensor for the discrimination of "self" and "non-self" signals to regulate the innate and adaptive immune system responses [44]. In further support of the glycome in the immune response, we have previously observed an inverse correlation between loss of sialic acid and LTreg counts in patients with ITP [4]. Failure of the immune system to correctly distinguish "self" is one hallmark of autoimmunity $[45,46]$.

Author Contributions: Conceptualization, supervision, writing—original draft preparation, review and editing: R.J.S., N.V.B. and M.T.Á.R. Funding acquisition: M.T.Á.R, V.J.Y. and N.V.B. Data curation: A.R.-L. and V.J.Y.; Methodology; validation; investigation, S.G.B., A.R.-L., E.M.M., P.A., M.I.R.P., E.G.A.-S., E.G.Z., M.M.S. and T.C. All authors have read and agreed to the published version of the manuscript.

Funding: This research was funded by FIS-Fondos FEDER PI19/00631, FIS-Fondos FEDER PI19/00772 and Platelet Disorder Support Association.

Institutional Review Board Statement: The study was conducted according to the guidelines of the Declaration of Helsinki, and approved by the Ethics Committee of Hospital Universitario La Paz (protocol code PI-3932, 9 January2020).

Informed Consent Statement: Informed consent was obtained from all subjects involved in the study.

Data Availability Statement: Data is contained within the article. 
Conflicts of Interest: M.T.A.R. and V.J.Y. have participated as speakers on advisory boards and sponsored symposia by Novo Nordisk, Takeda, Roche, Pfizer, Octapharma, Amgen, Novartis, CSL Behring and Sobi. N.V.B. has participated as speaker for Novo Nordisk, Takeda, Roche, Pfizer and Novartis. S.G.B. has participated as speaker and sponsored symposia by Novo Nordisk, Takeda, Roche, Pfizer, Novartis and Sobi. E.M.M. holds a predoctoral fellowship from Fundación Española de Trombosis y Hemostasia (FETH-SETH). R.J.S. currently is an employee at Takeda Farmacéutica España S.A. The rest of the authors have no conflict of interest to declare. The funders had no role in the design of the study; in the collection, analyses, or interpretation of data; in the writing of the manuscript; or in the decision to publish the results.

\section{References}

1. Rodeghiero, F.; Stasi, R.; Gernsheimer, T.; Michel, M.; Provan, D.; Arnold, D.M.; Bussel, J.B.; Cines, D.B.; Chong, B.H.; Cooper, N.; et al. Standardization of Terminology, Definitions and Outcome Criteria in Immune Thrombocytopenic Purpura of Adults and Children: Report from an International Working Group. Blood 2009, 113, 2386-2393. [CrossRef]

2. Cooper, N.; Ghanima, W. Immune Thrombocytopenia. N. Engl. J. Med. 2019, 381, 945-955. [CrossRef]

3. Swinkels, M.; Rijkers, M.; Voorberg, J.; Vidarsson, G.; Leebeek, F.W.G.; Jansen, A.J.G. Emerging Concepts in Immune Thrombocytopenia. Front. Immunol. 2018, 9, 880. [CrossRef]

4. MonzonManzano, E.; Alvarez Roman, M.T.; Justo Sanz, R.; Fernandez Bello, I.; Hernandez, D.; Martin Salces, M.; Valor, L.; Rivas Pollmar, I.; Butta, N.V.; Jimenez Yuste, V. Platelet and Immune Characteristics of Immune Thrombocytopaenia Patients Non-Responsive to Therapy Reveal Severe Immune Dysregulation. Br. J. Haematol. 2020, 189, 943-953. [CrossRef] [PubMed]

5. Audia, S.; Mahevas, M.; Samson, M.; Godeau, B.; Bonnotte, B. Pathogenesis of Immune Thrombocytopenia. Autoimmun. Rev. 2017, 16, 620-632. [CrossRef] [PubMed]

6. Mammadova-Bach, E.; Jaeken, J.; Gudermann, T.; Braun, A. Platelets and Defective N-Glycosylation. Int. J. Mol. Sci. 2020, 21, 5630. [CrossRef]

7. Lauc, G.; Pezer, M.; Rudan, I.; Campbell, H. Mechanisms of Disease: The human N-glycome. Biochim. Biophys. Acta 2016, 1860, 1574-1582. [CrossRef] [PubMed]

8. Kunicki, T.J.; Cheli, Y.; Moroi, M.; Furihata, K. The influence of N-linked Glycosylation on the Function of Platelet Glycoprotein VI. Blood 2005, 106, 2744-2749. [CrossRef] [PubMed]

9. Wang, Y.; Jobe, S.M.; Ding, X.; Choo, H.; Archer, D.R.; Mi, R.; Ju, T.; Cummings, R.D. Platelet Biogenesis and Functions Require Correct Protein O-Glycosylation. Proc. Natl. Acad. Sci. USA 2012, 109, 16143-16148. [CrossRef] [PubMed]

10. Li, R.; Hoffmeister, K.M.; Falet, H. Glycans and the Platelet Life Cycle. Platelets 2016, 27, 505-511. [CrossRef]

11. Rumjantseva, V.; Grewal, P.K.; Wandall, H.H.; Josefsson, E.C.; Sorensen, A.L.; Larson, G.; Marth, J.D.; Hartwig, J.H.; Hoffmeister, K.M. Dual Roles for Hepatic Lectin Receptors in the Clearance of Chilled Platelets. Nat. Med. 2009, 15, 1273-1280. [CrossRef] [PubMed]

12. Grozovsky, R.; Begonja, A.J.; Liu, K.; Visner, G.; Hartwig, J.H.; Falet, H.; Hoffmeister, K.M. The Ashwell-Morell Receptor Regulates Hepatic Thrombopoietin Production via JAK2-STAT3 Signaling. Nat. Med. 2015, 21, 47-54. [CrossRef] [PubMed]

13. Alvarez-Roman, M.T.; Rivas Pollmar, M.I.; Bernardino, J.I.; Lozano, M.L.; Martin-Salces, M.; Fernandez-Bello, I.; Jimenez-Yuste, V.; Butta, N.V. Thrombopoietin Receptor Agonists in Conjunction with Oseltamivir for Immune Thrombocytopenia. Aids 2016, 30, 1141-1142. [CrossRef] [PubMed]

14. Revilla, N.; Corral, J.; Minano, A.; Mingot-Castellano, M.E.; Campos, R.M.; Velasco, F.; Gonzalez, N.; Galvez, E.; Berrueco, R.; Fuentes, I.; et al. Multirefractory Primary Immune Thrombocytopenia; Targeting the Decreased Sialic Acid Content. Platelets 2019, 30, 743-751. [CrossRef] [PubMed]

15. Shao, L.; Wu, Y.; Zhou, H.; Qin, P.; Ni, H.; Peng, J.; Hou, M. Successful Treatment with Oseltamivir Phosphate in a Patient with Chronic Immune Thrombocytopenia Positive for Anti-GPIb/IX Autoantibody. Platelets 2015, 26, 495-497. [CrossRef]

16. van der Wal, D.E.; Davis, A.M.; Mach, M.; Marks, D.C. The Role of Neuraminidase 1 and 2 in Glycoprotein Ibalpha-Mediated Integrin Alphaiibbeta3 Activation. Haematologica 2020, 105, 1081-1094. [CrossRef] [PubMed]

17. Erlandsen, S.L.; Greet Bittermann, A.; White, J.; Leith, A.; Marko, M. High-Resolution CryoFESEM of Individual Cell Adhesion Molecules (CAMs) in the Glycocalyx of Human Platelets: Detection of P-Selectin (CD62P), GPI-IX Complex (CD42A/CD42B alpha,B beta), and Integrin GPIIbIIIa (CD41/CD61) by Immunogold Labeling and Stereo Imaging. J. Histochem. Cytochem. Off. J. Histochem. Soc. 2001, 49, 809-819. [CrossRef]

18. Li, J.; van der Wal, D.E.; Zhu, G.; Xu, M.; Yougbare, I.; Ma, L.; Vadasz, B.; Carrim, N.; Grozovsky, R.; Ruan, M.; et al. Desialylation is a Mechanism of Fc-Independent Platelet Clearance and a Therapeutic Target in Immune Thrombocytopenia. Nat. Commun. 2015, 6, 7737. [CrossRef]

19. Miyagi, T.; Yamaguchi, K. Mammalian Sialidases: Physiological and Pathological Roles in Cellular Functions. Glycobiology 2012, 22, 880-896. [CrossRef]

20. Monti, E.; Miyagi, T. Structure and Function of Mammalian Sialidases. Top. Curr. Chem. 2015, 366, 183-208. [CrossRef]

21. Li, J.; Callum, J.L.; Lin, Y.; Zhou, Y.; Zhu, G.; Ni, H. Severe Platelet Desialylation in a Patient with Glycoprotein Ib/IX AntibodyMediated Immune Thrombocytopenia and Fatal Pulmonary Hemorrhage. Haematologica 2014, 99, e61-e63. [CrossRef] 
22. Qiu, J.; Liu, X.; Li, X.; Zhang, X.; Han, P.; Zhou, H.; Shao, L.; Hou, Y.; Min, Y.; Kong, Z.; et al. CD8(+) T Cells Induce Platelet Clearance in the Liver via Platelet Desialylation in Immune Thrombocytopenia. Sci. Rep. 2016, 6, 27445. [CrossRef] [PubMed]

23. Millar, C.M.; Brown, S.A. Oligosaccharide Structures of von Willebrand Factor and Their Potential Role in von Willebrand Disease. Blood Rev. 2006, 20, 83-92. [CrossRef] [PubMed]

24. Sorensen, A.L.; Rumjantseva, V.; Nayeb-Hashemi, S.; Clausen, H.; Hartwig, J.H.; Wandall, H.H.; Hoffmeister, K.M. Role of Sialic Acid for Platelet Life Span: Exposure of Beta-Galactose Results in the Rapid Clearance of Platelets from the Circulation by Asialoglycoprotein Receptor-Expressing Liver Macrophages and Hepatocytes. Blood 2009, 114, 1645-1654. [CrossRef] [PubMed]

25. van der Wal, D.E.; Verhoef, S.; Schutgens, R.E.; Peters, M.; Wu, Y.; Akkerman, J.W. Role of Glycoprotein Ibalpha Mobility in Platelet Function. Thromb. Haemost. 2010, 103, 1033-1043. [CrossRef]

26. Riswari, S.F.; Tunjungputri, R.N.; Kullaya, V.; Garishah, F.M.; Utari, G.S.R.; Farhanah, N.; Overheul, G.J.; Alisjahbana, B.; Gasem, M.H.; Urbanus, R.T.; et al. Desialylation of Platelets Induced by Von Willebrand Factor is a Novel Mechanism of Platelet Clearance in Dengue. PLoS Pathog. 2019, 15, e1007500. [CrossRef]

27. Li, L.; Qu, C.; Lu, Y.; Gong, Y.; You, R.; Miao, L.; Guo, S. The Platelet Surface Glycosylation Caused by Glycosidase has a Strong Impact on Platelet Function. Blood Coagul. Fibrinolysis 2019, 30, 217-223. [CrossRef]

28. Bellucci, S.; Huisse, M.G.; Boval, B.; Hainaud, P.; Robert, A.; Fauvel-Lafeve, F.; Jandrot-Perrus, M. Defective Collagen-Induced Platelet Activation in Two Patients with Malignant Haemopathies is Related to a Defect in the GPVI-Coupled Signalling Pathway. Thromb. Haemost. 2005, 93, 130-138. [CrossRef]

29. Toonstra, C.; Hu, Y.; Zhang, H. Deciphering the Roles of N-Glycans on Collagen-Platelet Interactions. J. Proteome Res. 2019, 18, 2467-2477. [CrossRef]

30. Cai, X.; Thinn, A.M.M.; Wang, Z.; Shan, H.; Zhu, J. The importance of N-glycosylation on beta3 Integrin Ligand Binding and Conformational Regulation. Sci. Rep. 2017, 7, 4656. [CrossRef]

31. Wandall, H.H.; Rumjantseva, V.; Sorensen, A.L.; Patel-Hett, S.; Josefsson, E.C.; Bennett, E.P.; Italiano, J.E., Jr.; Clausen, H.; Hartwig, J.H.; Hoffmeister, K.M. The Origin and Function of Platelet Glycosyltransferases. Blood 2012, 120, 626-635. [CrossRef]

32. Grewal, P.K.; Uchiyama, S.; Ditto, D.; Varki, N.; Le, D.T.; Nizet, V.; Marth, J.D. The Ashwell Receptor Mitigates the Lethal Coagulopathy of Sepsis. Nat. Med. 2008, 14, 648-655. [CrossRef]

33. Lee-Sundlov, M.B.R.; Grozovsky, R.; Giannini, S.; Rivadeneyra, L.; Zheng, Y.; Glabere, S.; Kahr, W.H.; Abdi, R.; Wang, D.; Hoffmeister, K.M. Plasmacytoid Dendritic Cells Surveil Megakaryocyte Sialic Acid to Regulate Thrombopoiesis. Blood 2020, 136, 12-13. [CrossRef]

34. Lee-Sundlov, M.M.; Stowell, S.R.; Hoffmeister, K.M. Multifaceted role of glycosylation in transfusion medicine, platelets, and red blood cells. J. Thromb. Haemost. 2020, 18, 1535-1547. [CrossRef] [PubMed]

35. Ramstrom, S.; O’Neill, S.; Dunne, E.; Kenny, D. Annexin V Binding to Platelets is Agonist, Time and Temperature Dependent. Platelets 2010, 21, 289-296. [CrossRef] [PubMed]

36. Grodzielski, M.; Goette, N.P.; Glembotsky, A.C.; Pietto, M.C.B.; Mendez-Huergo, S.P.; Pierdominici, M.S.; Montero, V.S.; Rabinovich, G.A.; Molinas, F.C.; Heller, P.G.; et al. Multiple Concomitant Mechanisms Contribute to Low Platelet Count in Patients with Immune Thrombocytopenia. Sci. Rep. 2019, 9, 2208. [CrossRef]

37. Hoffmeister, K.M.; Josefsson, E.C.; Isaac, N.A.; Clausen, H.; Hartwig, J.H.; Stossel, T.P. Glycosylation Restores Survival of Chilled Blood Platelets. Science 2003, 301, 1531-1534. [CrossRef]

38. Josefsson, E.C.; Gebhard, H.H.; Stossel, T.P.; Hartwig, J.H.; Hoffmeister, K.M. The Macrophage Alphambeta2 Integrin Alpham Lectin Domain Mediates the Phagocytosis of Chilled Platelets. J. Biol. Chem. 2005, 280, 18025-18032. [CrossRef] [PubMed]

39. Cedzynski, M.; Swierzko, A.S. Components of the Lectin Pathway of Complement in Haematologic Malignancies. Cancers 2020, 12, 1792. [CrossRef] [PubMed]

40. Orsini, F.; Fumagalli, S.; Csaszar, E.; Toth, K.; De Blasio, D.; Zangari, R.; Lenart, N.; Denes, A.; De Simoni, M.G. Mannose-Binding Lectin Drives Platelet Inflammatory Phenotype and Vascular Damage After Cerebral Ischemia in Mice via IL (Interleukin)-1alpha. Arterioscler. Thromb. Vasc. Biol. 2018, 38, 2678-2690. [CrossRef] [PubMed]

41. Saevarsdottir, S.; Vikingsdottir, T.; Valdimarsson, H. The Potential Role of Mannan-Binding Lectin in the Clearance of SelfComponents Including Immune Complexes. Scand. J. Immunol. 2004, 60, 23-29. [CrossRef] [PubMed]

42. Castelli, R.; LambertenghiDelilliers, G.; Gidaro, A.; Cicardi, M.; Bergamaschini, L. Complement Activation in Patients with Immune Thrombocytopenic Purpura According to Phases of Disease Course. Clin. Exp. Immunol. 2020, 201, 258-265. [CrossRef] [PubMed]

43. Peerschke, E.I.; Andemariam, B.; Yin, W.; Bussel, J.B. Complement Activation on Platelets Correlates with a Decrease in Circulating Immature Platelets in Patients with Immune Thrombocytopenic Purpura. Br. J. Haematol. 2010, 148, 638-645. [CrossRef] [PubMed]

44. Crocker, P.R. Siglecs in Innate Immunity. Curr. Opin. Pharmacol. 2005, 5, 431-437. [CrossRef] [PubMed]

45. Baum, L.G.; Cobb, B.A. The Direct and Indirect Effects of Glycans on Immune Function. Glycobiology 2017, 27, 619-624. [CrossRef] [PubMed]

46. Maverakis, E.; Kim, K.; Shimoda, M.; Gershwin, M.E.; Patel, F.; Wilken, R.; Raychaudhuri, S.; Ruhaak, L.R.; Lebrilla, C.B. Glycans in the Immune System and The Altered Glycan Theory of Autoimmunity: A Critical Review. J. Autoimmun. 2015, 57, 1-13. [CrossRef] 